\title{
LEVEL KEMAMPUAN PEMECAHAN MASALAH MATEMATIKA SISWA PADA MATERI GEOMETRI
}

\author{
Palupi Sri Wijayanti, Kintoko, Rizky Ananda Setiawan \\ Universitas PGRI Yogyakarta, Indonesia \\ kintoko@upy.ac.id
}

\begin{abstract}
One of the objectives of learning mathematics at the primary to secondary level is to facilitate students' problem solving abilities. This study aims to determine the level of students' mathematical problem solving abilities. This type of research is descriptive quantitative with the main data source being the scores of students' mathematical problem solving abilities. The research procedure was carried out in three stages, namely preparation, implementation, and final. The research data obtained were processed and analyzed using quantitative techniques and then it was described that the level of students' mathematical problem solving abilities was at a certain level. Based on the results of data processing and adjusted to the research objectives, it can be stated that the results of research that show the level of student's problem solving ability are included in bigh criteria for indicators of easy understanding of problems, sufficient for indicators of being able to plan strategies, very bigh criteria for classifying indicators of implementing plans, and very spatial for indicators to check the answer again

Keywords: problem solving, online learning, student learning levels.
\end{abstract}

\begin{abstract}
ABSTRAK
Tujuan pembelajaran matematika di tingkat dasar hingga menengah salah satunya adalah memfasilitasi kemampuan pemecahan masalah siswa. Penelitian ini bertujuan untuk mengetahui level kemampuan pemecahan masalah matematika siswa. Jenis penelitian ini adalah deskriptif kuantitatif dengan sumber data utama adalah skor kemampuan pemecahan masalah matematika siswa. Prosedur penelitian dilakukan dengan tiga tahapan yaitu persiapan, pelaksanaan, dan akhir. Data penelitian yang diperoleh diolah dan dianalisis menggunakan teknik kuantitatif kemudian dideskripsikan tingkat kemampuan pemecahan masalah matematika siswa berada pada level tertentu. Berdasarkan hasil pengolahan data dan disesuaikan dengan tujuan penelitian maka dapat disebutkan hasil penelitian yang menunjukkan level kemampuan pemecahan masalah siswa termasuk dalam kriteria tinggi untuk indikator mudah memahami permasalahan, cukup untuk indicator mampu merancakan strategi, kriteria sangat tinggi untuk menggolongkan indicator melaksanakan rencana, dan sangat rencah untuk indicator mengecek kembali jawaban.
\end{abstract}

Kata Kunci: kemampuan pemecahan masalah, pembelajaran daring, tingkat belajar siswa.

Submitted Nov 25, 2020 | Revised Des 13, 2020 | Accepted Des 18, 2020

\section{Pendahuluan}

Pembelajaran matematika dari tingkat dasar hingga menengah memiliki tujuan yang tidak lepas dari meningkatkan kemampuan pemecahan masalah matematika siswa. Kemampuan pemecahan masalah (problem solving) dapat dikatakan sebagai media dalam mengkorelasikan pengetahuan dan kemampuan seseorang berdasarkan pengalaman yang telah dimiliki sebelumnya untuk selanjutnya disentesis dan digunakan pada permasalahan yang berbeda dan kemungkinan baru dihadapi Krulik dan Rudnick (1995). Pengetahuan siswa yang telah dimilikinya melalui kegiatan pemahaman akan berguna untuk mengembangkan pengetahuan baru dalam proses penyelesaian permasalahan yang tidak biasa (unfamiliar) (Suhandri et al., 2017). Selebihnya, kemampuan pemecahan masalah akan mampu memfasilitasi kemampuan siswa dalam menginvestigasi permasalahan lebih focus dan dalam sehingga siswa akan memiliki pengetahuan yang terkonstruksi untuk memperoleh kemungkinan penyelesaian permasalahan dengan kreasi yang inovatif dan kreatif (Susanti et al., 2017).

Kemampuan pemecahan masalah siswa satu dengan yang lain berbeda tingkatan atau levelnya tergantung dari tingkat kemampuan siswa dalam memahami permasalahan, ketelitian dalam menemukan data, serta memahami konsep-konsep matematika yang saling berkaitan. Proses 
pemecahan masalah matematika merupakan kegiatan untuk mengatasi kesulitan-kesulitan yang dihadapi dala mencapai tujuan atau kompetensi yang diharapkan (Sumartini, 2018).

Level kemampuan pemecahan masalah matematika siswa dapat menentukan kemampuan tingkat kompetensi siswa dalam menguasai kompetensi dasar dalam pelajaran tersebut. Kompetensi dasar matematika yang harus dikuasai oleh para siswa ditentukan berdasarkan indikator pencapaian kompetensi dan tujuan pembelajaran yang sedang berlangsung. Kemampuan pemecahan masalah memang sebaiknya dimiliki pleh siswa agar dapat memberikan latihan dan terbiasa dalam menghadapi berbagai permasalahan, baik terkait dengan matematika ataupun dengan bidang studi yang lain atau bahkan masalah dalam kehidupan sehari-hari yang cenderung lebih kompleks (Lestari et al., 2019).

Kemampuan pemecahan masalah dapat dikatakan sebagai salah satu kemampuan patut dimiliki para siswa dalam belajar matematika (Mulyati, 2016). Secara khusus, kemampuan ini dapat digunakan untuk mengembangkan kemampuan individu dalam memecahkan masalah yang dihadapinya dalam kehidupan sehari-hari sehingga dapat meningkatkan ketrampilan diri siswa. Hal tersebut juga didukung dengan kurikulum internasional yang terangkum dalam National Council of Supervisors of Mathematics (NCTM) yang menyatakan bahwa problem solving must be the focus of the curriculum. Selain itu, terdapat penekanan yang disebutkan oleh National Council of Supervisors of Mathematics (NCSM) dengan pernyataan bahwa "learning to solve problems is the principal reason for studying mathematics"(Mulyati, 2016).

Pembelajaran matematika di tingkat dasar dan menengah masih memuat materi geometri sehingga diharapkan mampu untuk membekali para siswa dalam memahami permasalahan yang berkaitan dengan bidang datar, bidang ruang, maupun benda-benda geometris lainnya. Materi pelajaran pada bahasan geometri tidak lepas dari pembahasan persegi, persegi panjang, garis, titik, luas, keliling, maupun volume dan luas permukaan. Hal ini menuntun siswa untuk lebih mudah dalam memiliki kemampuan berfikir logis dan sistematis dan mengaitkan dalam beberapa konsep matematika yang saling berhubungan.

Dalam pembelajaran geometri, kemampuan pemecahan masalah dapat diasah dengan pemberian variasi soal yang beragam karena materi geometri sangatlah dekat dengan kehidupan para siswa. Terlebih lagi dengan benda-benda yang ada disekitar lingkungan para siswa. Hal ini dapat membantu siswa dalam mengasah kemampuan pemecahan masalahnya hingga pada level yang lebih baik. Secara logika, pemecahan masalah siswa dapat membantu untuk menutup kesenjangan mengenai apa yang diharapkan dengan apa yang dapat dilakukan (Samo, 2017).

Pembelajaran matematika di sekolah, berdasar dari hasil observasi peneliti diperoleh bahwa tingkat kemampuan pemecahan masalah matematika siswa cenderung belum maksimal. Kecenderungan tersebut disebabkan oleh permasalahan matematika yang dihadapi siswa berpotensi untuk langsung dikerjakan dengan menerapkan operasi berkaitan dengan konsep rumus yang digunakan dalam menyelesaikan permasalahan tersebut. Hal ini terlihat dari prosedur penyelesaian yang disajikan siswa dalam lembar jawaban yang masih termasuk dalam level kurang tepat atau dapat dikatakan tidak benar. Siswa cenderung langsung menuliskan jawaban akhir tanpa menuliskan langkah-langkah awalnya terlebih dahulu. Hal ini membuka kecenderungan siswa dalam mengambil jawaban teman yang lain, sehingga pola berpikir siswa tidak dapat berkembang apabila hanya mencontek.

Padahal dalam pembelajaran matematika kemampuan pemecahan masalah matematis merupakan salah satu tujuan umum yang hendak dicapai. Hal ini dapat dikatakan pula bahwa kemampuan pemecahan masalah menjadi tujuan umum dalam proses belajar matematika dan termasuk dalam kemampuan dasar belajar matematika (Dewi et al., 2019). Kemampuan pemecahan masalah yang dilatih dengan menyelesaikan berdasarkan prosedur akan dapat melatih siswa dalam mengerjakan soal matematika yang membutuhkan sistematika secara logis. Para siswa yang telah terlatih dalam menghadapi permasalahan matematika akan lebih terampil dalam mengidentifikasi dan seleksi informasi yang sesuai dan relevan, menganalisis, dan proses evaluasi hasil yang diperoleh (Sundayana, 2018). 
Proses pemecahan masalah matematika dapat dikategorikan sebagai kegiatan kognitif yang sangat kompleks dalam menyelesaikan permasalahan dengan bervariasi strategi. Pemberian latihan siswa dalam menyelesaikan permasalahan matematika tidak hanya mengharapkan siswa sekedar mampu menyelesaikan permasalahan namun juga kebiasaannya dalam berfikir strategi yang tepat dalam proses pemecahan masalah sehingga diharapkan dapat memberikan inisiatif dalam menjalani hidup yang memiliki kompleksitas permasalahan (Fadillah, 2010). Secara difinisi, pemecahan masalah dapat diartikan secara rangkum sebagai proses individu dalam berfikir secara terarah dalam menentukan sesuatu hal terkait dengan proses penyelesaian permasalahan (Mawaddah \& Anisah, 2015).

Berdasarkan uraian di atas, maka dapat disimpulkan bahwa kemampuan pemecahan masalah matematika siswa sangatlah penting dalam proses pembelajaran matematika dan dapat digunakan untuk memfasilitasi siswa dalam mengembangkan proses berfikir hingga menjadi kebiasaan yang baik untuk berlogika secara sistematis. Kemampuan pemecahan masalah juga dapat diartikan sebagai kemampuan para siswa dalam proses berfikirnya untuk memperoleh solusi yang tepat dalam menyelesaikan permasalahan yang tengah dihadapinya.

Kemampuan pemecahan masalah matematika dapat dilihat dari beberapa indikator yang diuraikan dalam hal: (1) mengkonstruksi kognisi matematika yang baru melalui proses penyelesaian permasalahan, (2) menggunakan dan menyelaraskan strategi dan teknik yang tepat dalam memecahkan amsalah, (3) menyelesaikan permasalahan yang timbul dalam matematika dan konteks atau bidang yang lain, dan (4) mengecek serta melakukan refleksi terhadap proses pemecahan masalah matematika (Ulya, 2015).

Selanjutnya, terdapat pendapat lain yang menyebutkan bahwa indicator kemampuan pemecahan masalah matematika antara lain yaitu: menyelesaikan permasalahan dengan menerapkan strategi baik berkaitan ataupun tidak dengan matematika, memecahkan permasalahan nyata dan menyelesaiakan permasalahan dengan model matematika, menguraikan dan menginterferensikan proses perolehan solusi, menyebutkan data yang diketahui ataupun ditanyakan hingga kecukupan data, dan menyusun model matematika (Di Perri et al., 1996).

Dalam penelitian ini, digunakan empat indicator kemampuan pemecahan masalah yaitu: mengidentifikasi data-data yang telah diketahui, apa yang ditanyakan dan kecukupan data yang akan digunakan, menyusun permasalahan ke dalam model matematika, menggunakan strategi, dan menginterpretasikan hasil yang diperoleh dalam penyelesaian permasalahan.

Indicator kemampuan pemecahan masalah harus termuat dalam indicator soal. Indicator tersebut dapa dipisah dan dapat disajikan dalam satu soal namun dapat pula seluruh indicator kemampuan pemecahan masalah disajikan dalam satu soal. Hal tersebut tergantung kemampuan pembuat soal dalam menyusun kalimat permasalahan sehingga mampu memberikan gambaran dan instruksi untuk menggali kemampuan pemecahan masalah siswa (Amam, 2017). Dalam menentukan level kemampuan pemecahan masalah siswa, peneliti menggunakan acuan berdasarkan kriteria sebagai berikut.

Tabel 1. Level Kemampuan Pemecahan Masalah

\begin{tabular}{ll}
\hline Interval & Kategori \\
\hline $\mathrm{M}_{1}+1,5 \mathrm{Sd}_{1}<\mathrm{X} \leq \mathrm{M}_{1}+3 \mathrm{Sd}_{1}$ & Sangat tinggi \\
$\mathrm{M}_{1}+0,5 \mathrm{Sd}_{1}<\mathrm{X} \leq \mathrm{M}_{1}+1,5 \mathrm{Sd}_{1}$ & Tinggi \\
$\mathrm{M}_{1}-0,5 \mathrm{Sd}_{1}<\mathrm{X} \leq \mathrm{M}_{1}+0,5 \mathrm{Sd}_{1}$ & Cukup \\
$\mathrm{M}_{1}-1,5 \mathrm{Sd}_{1}<\mathrm{X} \leq \mathrm{M}_{1}-0,5 \mathrm{Sd}_{1}$ & Rendah \\
$\mathrm{M}_{1}-3 \mathrm{Sd}_{1}<\mathrm{X} \leq \mathrm{M}_{1}-1,5 \mathrm{Sd}_{1}$ & Sangat rendah \\
\hline
\end{tabular}

(Arfiana \& Wijaya, 2018)

Keterangan :

$\mathrm{M}_{1}=\frac{1}{2}$ (Skor max ideal - skor min ideal)

$\mathrm{Sd}_{1}=\frac{1}{6}($ Skor max ideal - skor min ideal) 


\section{Metode Penelitian}

Penelitian ini adalah penelitian deskriptif kuantitatif dengan subjek penelitian adalah siswa kelas VII SMP N 3 Jetis Yogyakarta. Penelitian dilakukan dengan tiga tahapan yaitu persiapan untuk menyiapkan beberapa hal terkait administrasi dalam pengambilan data dan penelitian termasuk di antaranya untuk administrasi kelengkapan pembelajaran. Selanjutnya adalah tahap pelaksanaan yaitu dengan mengambil data skor kemampuan pemecahan masalah matematika siswa dan tahap terakhir adalah proses pengolahan data untuk diketahui level kemampuan pemecahan masalah matematika siswa.

Teknik pengambilan data yang digunakan dalam penelitian ini teknik tes. Instrumen tes yang digunakan adalah tes kemampuan pemecahan masalah. Instrumen tes kemampuan pemecahan masalah matematika terdiri dari tiga soal yang disesuaikan dengan indicator pencapaian kompetensi pada materi segiempat meliputi: persegi, persegi panjang, jajargenjang dan trapesium. Teknik analisis data yang digunakan adalah analisis data kuantitatif untuk menentukan skor siswa dalam pencapaian kemampuan pemecahan masalah. Analisis dilakukan dengan melakukan perhitungan tiap indikator dan disesuaikan dengan tingkatan level skor yang diperoleh

\section{Hasil dan Pembahasan}

Berdasarkan hasil analisis data yang dilakukan oleh peneliti, diperoleh hasil penelitian bahwa level kemampuan pemecahan masalah matematika siswa yang dihitung melalui tiap indikator dan rata-rata pencapaian langkah kemampuan pemecahan masalah matematika adalah sebagai berikut:

Tabel 2. Level kemampuan pemecahan masalah

\begin{tabular}{cccc}
\hline No. Soal & Indikator & Nilai & Kategori \\
\hline 1 & A & 100,00 & Sangat tinggi \\
& B & 87,00 & Sangat tinggi \\
& C & 95,55 & Sangat tinggi \\
2 & D & 23,00 & Sangat rendah \\
& A & 90,00 & Sangat tinggi \\
& B & 37,00 & Rendah \\
& C & 62,00 & Tinggi \\
3 & D & 20,00 & Sangat rendah \\
& A & 87,00 & Sangat tinggi \\
& B & 41,67 & Rendah \\
& C & 73,33 & Tinggi \\
& D & 20,00 & Sangat rendah \\
\hline
\end{tabular}

Tabel 3. Rata-rata tes kemampuan pemecahan masalah tiap aspek

\begin{tabular}{ccl}
\hline $\begin{array}{c}\text { Indikator Pemecahan } \\
\text { Masalah Matematis }\end{array}$ & Rata-rata & \multicolumn{1}{c}{ Kategori } \\
\hline A & 92,33 & Sangat tinggi \\
B & 55,23 & Cukup \\
C & 76,96 & Sangat tinggi \\
D & 21,00 & Sangat Rendah \\
\hline
\end{tabular}

Keterangan:

A : mengidentifikasi data-data yang telah diketahui, apa

yang ditanyakan dan kecukupan data yang akan digunakan

B : menyusun permasalahan ke dalam model matematika

C : menggunakan strategi

$\mathrm{D}$ : menginterpretasikan hasil yang diperoleh dalam penyelesaian permasalahan

Hasil penelitian tersebut dapat memberika ulasan dan uraian bahwa pada tes nomor 1, semua siswa sudah menuliskan indikator A yaitu menjelaskan unsur yang diketahui dan ditanyakan, pada 
indikator B sebagian besar siswa merumuskan masalah namun hanya sedikit siswa yang tidak menuliskannya, pada indikator $C$ hampir semua siswa benar dalam menerapkan strategi penyelesaian masalah, sedangkan pada indikator D hanya beberapa siswa yang menginterpretasikan hasil penyelesaian masalah.

Selanjutnya, pada soal nomor 2 diperoleh hasil bahwa sebagian besar siswa sudah menuliskan indikator A yaitu menjelaskan unsur yang diketahui dan ditanyakan, pada indikator B ada beberapa siswa merumuskan masalah adapula siswa yang tidak menuliskannya, pada indikator $\mathrm{C}$ beberapa siswa benar dalam menerapkan strategi penyelesaian masalah ada juga siswa yang salah dalam menerapkan strategi penyelesaian masalah, sedangkan pada indicator D masih banyak siswa yang tidak menjelaskan atau menginterpretasikan hasil penyelesaian masalah. Sementara itu, pada soal nomor 3, sebagian besar siswa sudah menuliskan indikator A yaitu menjelaskan unsur yang diketahui dan ditanyakan, pada indikator B ada beberapa siswa merumuskan masalah adapula siswa yang tidak menuliskannya, pada indikator $\mathrm{C}$ beberapa siswa benar dalam menerapkan strategi penyelesaian masalah ada juga siswa yang salah dalam menerapkan strategi penyelesaian masalah, sedangkan pada indikator D masih banyak siswa yang tidak menjelaskan atau menginterpretasikan hasil penyelesaian masalah.

Dalam penelitian ini, dilakukan pengambilan data berdasarkan respon siswa yang menunjukkan bahwa soal nomor 1 mudah dipahami siswa dan diprosentasekan sebesar 76,7\%. Selebihnya, indikator A dengan nilai 100,00 dengan katerogi sangat tinggi artinya siswa mampu mengidentifikasi unsur-unsur yang diketahui dan ditanyakan dengan baik, indikator B dengan nilai 87,00 dengan kategori sangat tinggi artinya sebagian besar siswa dapat merumuskan masalah matematis, indikator $\mathrm{C}$ dengan nilai 95,00 dengan kategori sangat tinggi artinya sebagian besar siswa mampu menerapkan strategi dalam menyelesaikan masalah, sedangkan pada indikator D dengan nilai 23,00 dengan kategori rendah diketahui dari data banyak siswa tidak menjelaskan hasil penyelesaian masalah.

Pada soal nomor 2 menunjukkan bahwa termasuk cukup dipahami dengan besaran persentase $53,3 \%$. Secara garis besar diuraikan bahwa indikator A dengan nilai 90,00 dengan katerogi sangat tinggi artinya siswa mampu mengidentifikasi unsur-unsur yang diketahui dan ditanyakan dengan baik, indikator B dengan nilai 37,00 dengan kategori rendah artinya masih banyak siswa tidak menuliskan rumusan masalah matematis, indikator $\mathrm{C}$ dengan nilai 62,00 dengan kategori tinggi artinya sebagian besar siswa mampu menerapkan strategi dalam menyelesaikan masalah, sedangkan pada indikator D dengan nilai 20,00 dengan kategori rendah diketahui dari data banyak siswa tidak menjelaskan hasil penyelesaian masalah.

Pada soal nomor 3 menunjukkan respon siswa terhadap soal termasuk dalam cukup dipahami siswa sebesar 53,3\%. Secara persentase, indikator A dengan nilai 87,00 dengan katerogi sangat tinggi artinya siswa mampu mengidentifikasi unsur-unsur yang diketahui dan ditanyakan dengan baik, indikator B dengan nilai 41,67 dengan kategori rendah artinya masih banyak siswa tidak menuliskan rumusan masalah matematis, indikator $\mathrm{C}$ dengan nilai 73,33 dengan kategori tinggi artinya sebagian besar siswa mampu menerapkan strategi dalam menyelesaikan masalah, sedangkan pada indikator D dengan nilai 20,00 dengan kategori rendah diketahui dari data banyak siswa tidak menjelaskan hasil penyelesaian masalah.

\section{Kesimpulan}

Berdasarkan hasil dan pembahasan, maka dapat disimpulkan bahwa pengkategorian pemecahan masalah matematika instrumen tes matematika ke-1 (TM ke-1) diperoleh indikator A mempunyai ratarata 92,33 dikategorikan sangat tinggi, indikator B mempunyai rata-rata 55,23 dikategorikan cukup, indikator $\mathrm{C}$ mempunyai rata-rata 76,96 dikategorikan sangat tinggi, indikator D mempunyai rata-rata 21,00. Saran yang dapat disampaikan peneliti yaitu untuk melakukan analisis soal secara kuantitatif bertujuan agar dapat mengetahui sejauh mana keefektifan tes itu sendiri guna meningkatkan kualitas tes, dalam pembuatan soal hendaknya tidak terlalu sulit dan tidak terlalu mudah agar dapat seimbang, 
dan apabila setelah dilakukannya analisis secara kuantitatif menemui butir soal yang belum berfungsi dengan baik sebaiknya diperbaiki dan untuk soal tes yang sudah befungsi dengan baik dapat digunakan sebagai referensi tes yang akan datang

\section{Daftar Pustaka}

Amam, A. (2017). Penilaian Kemampuan Pemecahan Masalah Matematis Siswa Smp. Teorema, 2(1), 39. https://doi.org/10.25157/.v2i1.765

Arfiana, A., \& Wijaya, A. (2018). Problem solving skill of students of senior high schools and Islamic high schools in Tegal Regency in solving the problem of PISA based on Polya's stage. Jurnal Riset Pendidikan Matematika, 5(2), 211-222. https://doi.org/10.21831/jrpm.v5i2.15783

Dewi, N. P. R., Ardana, I. M., \& Sariyasa, S. (2019). Efektivitas Model ICARE Berbantuan Geogebra Untuk Meningkatkan Kemampuan Pemecahan Masalah Matematis Siswa. JNPM Jumal Nasional Pendidikan Matematika), 3(1), 109. https://doi.org/10.33603/jnpm.v3i1.1762

Di Perri, G., Cazzadori, A., Vento, S., Bonora, S., Malena, M., Bontempini, L., Lanzafame, M., Allegranzi, B., \& Concia, E. (1996). Comparative histopathological study of pulmonary tuberculosis in human immunodeficiency virus-infected and non-infected patients. Tubercle and Lung Disease, 77(3), 244-249. https://doi.org/10.1016/S0962-8479(96)90008-8

Fadillah, S. (2010). Kemampuan Pemecahan Masalah Matematis dalam Pembelajaran Matematika. Prosiding Seminar Nasional Penelitian, Pendidikan Dan Penerapan MIPA, Fakultas MIPA, Universitas Negeri Yogyakarta, 1(4), 338-553.

Lestari, I., Andinny, Y., \& Mailizar, M. (2019). Pengaruh Model Pembelajaran Situation Based Learning dan Kemandirian Belajar Terhadap Kemampuan Pemecahan Masalah Matematis. JNPM Jurnal Nasional Pendidikan Matematika), 3(1), 95. https://doi.org/10.33603/jnpm.v3i1.1748

Mawaddah, S., \& Anisah, H. (2015). Kemampuan Pemecahan Masalah Matematis Siswa Pada Pembelajaran Matematika dengan Menggunakag) di SMPn Model Pembelajaran Generatif (Generative Learning) di SMP. EDU-MAT: Jurnal Pendidikan Matematika, 3(2), 166-175. https://doi.org/10.20527/edumat.v3i2.644

Mulyati, T. (2016). Kemampuan Pemecahan Masalah Matematis Siswa Sekolah Dasar (Mathematical Problem Solving Ability of Elementary School Students). EDUHUMANIORA: Jurnal Pendidikan Dasar, 3(2), 1-20.

Samo, D. D. (2017). Kemampuan pemecahan masalah matematika mahasiswa tahun pertama dalam memecahkan masalah geometri konteks budaya. Jurnal Riset Pendidikan Matematika, 4(2), 141. https://doi.org/10.21831/jrpm.v4i2.13470

Suhandri, S., Nufus, H., \& Nurdin, E. (2017). Profil Kemampuan Koneksi Matematis Mahasiswa dalam Menyelesaikan Masalah Matematika Berdasarkan Level Kemampuan Akademik. Jurnal Analisa, 3(2), 115-129. https://doi.org/10.15575/ja.v3i2.2012

Sumartini, T. S. (2018). Peningkatan Kemampuan Pemecahan Masalah Matematis Siswa melalui Pembelajaran Berbasis Masalah. Mosharafa: Jurnal Pendidikan Matematika, 5(2), 148-158. https://doi.org/10.31980/mosharafa.v5i2.270

Sundayana, R. (2018). Kaitan antara Gaya Belajar, Kemandirian Belajar, dan Kemampuan Pemecahan Masalah Siswa SMP dalam Pelajaran Matematika. Mosharafa: Jumal Pendidikan Matematika, 5(2), 75-84. https://doi.org/10.31980/mosharafa.v5i2.262

Susanti, S., Musdi, E., \& Syarifuddin, H. (2017). Pengembangan Perangkat Pembelajaran Matematika Berbasis Penemuan Terbimbing untuk Meningkatkan Kemampuan Pemecahan Masalah Matematis Materi Statistika. JNPM (Jurnal Nasional Pendidikan Matematika), 1(2), 305. https://doi.org/10.33603/jnpm.v1i2.561

Ulya, H. (2015). Hubungan Gaya Kognitif Dengan Kemampuan Pemecahan Masalah Matematika Siswa. Jurnal Konseling Gusjigang, 1(2). https:/ / doi.org/10.24176/jkg.v1i2.410 